Chem. Ber. 117, 246-259 (1984)

\title{
[3.3]- and [4.4](2,7)Pyrenophanes as Excimer Models: Synthesis, Molecular Structure, and Spectroscopic Properties
}

\author{
Heinz A. Staab*, Norbert Riegler, François Diederich, Claus Krieger, \\ and Dieter Schweitzer
}

Max-Planck-Institut für medizinische Forschung, Abteilung Organische Chemie, and Abteilung Molekulare Physik, Jahnstr. 29, D-6900 Heidelberg

Received March 15, 1983

As excimer models the [3.3]- and [4.4]pyrenophanes 1 and 2 were synthesized. As the key precursor for the synthesis of 1 the octahydro-dithia[4.4]pyrenophane 9 was obtained by cyclisation of 4 and $\mathbf{8}$, the syntheses of which are described. Disulfone 10, derived from 9, on vapour-phase pyrolysis yielded 11 which by dehydrogenation was converted into 1 . In an analogous route 2 was obtained via 16, 17, and 18 starting from 4 and 15 (prepared in the reaction sequence $12 \rightarrow 13 \rightarrow$ $14 \rightarrow 15$ ). - The molecular structures of 1 and 2 , determined by $X$-ray structure analyses, are discussed with regard to transanular distances and deviations from planarity of the pyrene units. - Absorption spectra of $\mathbf{1}$ and $\mathbf{2}$ are discussed with reference to transanular interactions. The fluorescence emissions of 1 and 2 are found to be 'excimer-like'. Results obtained by ODMR measurements of 1 are reported.

[3.3]- und [4.4](2,7)Pyrenophane als Excimeren-Modelle: Synthese, Molekülstruktur und spektroskopische Eigenschaften

Als Excimeren-Modelle wurden die [3.3]- und [4.4]Pyrenophane 1 und 2 synthetisiert. Als Vorstufe für die Synthese von 1 wurde das Octahydro-dithia[4.4]pyrenophan 9 durch Cyclisierung von 4 und 8 erhalten, deren Synthese beschrieben wird. Das von 9 abgeleitete Disulfon 10 ergab durch Gasphasen-Pyrolyse 11, das durch Dehydrierung in 1 ubergeführt wurde. Auf analogem Wege wurde 2 über 16, 17 und 18 ausgehend von 4 und 15 (dargestellt in der Reaktionsfolge $12 \rightarrow 13 \rightarrow$ $14 \rightarrow 15$ ) erhalten. - Die Molekülstrukturen von 1 und 2 wurden durch Röntgen-Strukturanalyse bestimmt; sie werden im Hinblick auf transanulare Abstande und Abweichungen von der Planarität der Pyren-Einheiten diskutiert. - Die Absorptionsspektren von 1 und 2 werden im Zusammenhang mit der transanularen Wechselwirkung diskutiert. Die Fluoreszenz-Emission von 1 und 2 entspricht dem Excimeren-Charakter dieser Verbindungen. Ergebnisse, die durch ODMRMessungen an 1 erhalten wurden, werden mitgeteilt.

The first and most typical example of an 'excimer' formation has been observed for pyrene $^{1)}$. On photoexcitation a complex is formed by an excited pyrene molecule with a second pyrene which is in the electronic ground state: $\mathrm{Ar} r^{*}+\mathrm{Ar} \rightleftharpoons\left(\mathrm{Ar}_{2}\right)^{*}$ (excited dimer $=$ 'excimer'). Whereas absorption spectra are not affected, excimer formation results in a concentration dependent change in the fluorescence emission which, as compared to monomer emission, is strongly red-shifted, broad, and structureless. In spite of the undisputed importance of excimers for the photophysics and photochemistry of aromatic systems, so far only very limited experimental evidence has been 
available concerning the sterical structure of excimers, i.e. the mutual orientation and the distance of the components. Recently, compounds with two aromatic units fixed intramolecularly in a well-defined geometry found increasing interest as excimer models ${ }^{2}$. In this connection [2.2] $(2,7)$ pyrenophane has been synthesized ${ }^{3)}$ which in fact shows spectroscopic properties in accordance with an intramolecular excimer analogue ${ }^{4}$. As X-ray structure analysis showed, however, the aromatic $\pi$-systems in $[2.2](2,7)$ pyrenophane deviate strongly from planarity due to the high sterical strain present in this [2.2]phane structure ${ }^{3 \mathrm{~d})}$. Under this aspect, the higher homologues [3.3](2,7)pyrenophane (1) and [4.4](2,7)pyrenophane (2) seemed to be of special interest as excimer models since here nearly, or even completely, planar pyrene units were to be expected. We report here on the synthesis of $\mathbf{1}$ and $\mathbf{2}$, on the determination of their molecular structures by X-ray analysis, and on spectroscopic properties as related to the excimer state.

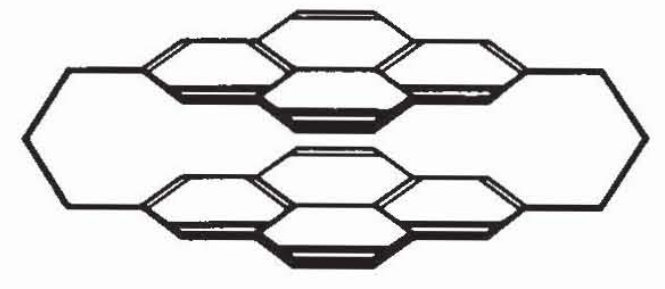

1

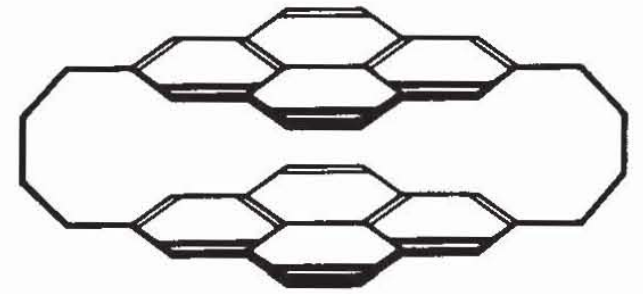

2

\section{Synthesis of $[3.3](2,7)$ Pyrenophane (1)}

For the preparation of the pyrene derivatives needed for the cyclisation to 1, direct functionalisation of pyrene or tetrahydropyrene proved to be unconvenient in yield and procedure considering the long synthetic route to follow. Instead, we made use of the approach via correspondingly substituted [2.2]metacyclophanes as suggested by Misumi et al. ${ }^{3 a}$ ) and Mitchell et al. ${ }^{3 b}$. Following these procedures with slight modifications 2,7-bis(bromomethyl)-4,5,9,10-tetrahydropyrene (3) was prepared starting from 1,3-bis(bromomethyl)- and 1,3-bis(mercaptomethyl)-5-methylbenzenes. From 3 by the thiourea method 4,5,9,10-tetrahydro-2,7-bis(mercaptomethyl)pyrene (4) was obtained as the first cyclisation component for the synthesis of $\mathbf{1}$. For the second component the extension of the side chains to $\mathrm{C}_{2}$-units was necessary. For this purpose, 3 was converted to the 2,7-bis(cyanomethyl) compound 5 ( $\mathrm{NaCN}$, dimethyl sulfoxide,

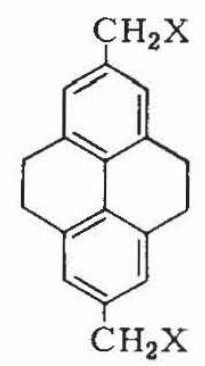

3: $\mathrm{X}=\mathrm{Br}$

4: $\mathrm{X}=\mathrm{SH}$

5: $\mathrm{X}=\mathrm{CN}$

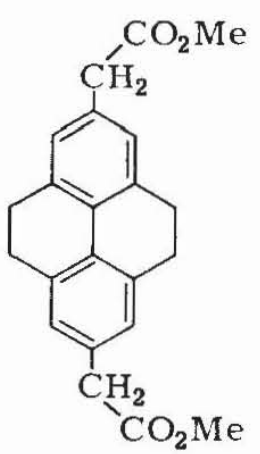

6

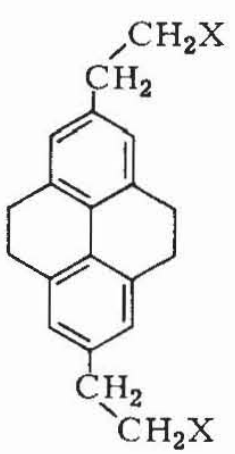

7: $\mathrm{X}=\mathrm{OH}$

8: $\mathrm{X}=\mathrm{Br}$

Chem. Ber. 117(1984) 
$20^{\circ} \mathrm{C} ; 83 \%$ ) which with hydrogen chloride/methanol yielded dimethyl $4,5,9,10$ tetrahydro-2,7-pyrenediacetate $(6 ; 95 \%)$. Lithium aluminum hydride reduction led to 4,5,9,10-tetrahydro-2,7-bis(2-hydroxyethyl)pyrene $(7 ; 82 \%)$ which with tetrabromomethane/triphenylphosphane was converted into the 2,7-bis(2-bromoethyl) compound $8(88 \%)$.

Cyclisation of $\mathbf{4}$ and 8 [potassium carbonate, boil. ethanol/tert-butyl alcohol (1:1), high dilution] yielded $7,8,12,13,21,22,26,27$-octahydro-2,17-dithia[4.4](2,7)pyrenophane $(9 ; 53 \%)$. Oxidation with 3-chloroperoxybenzoic acid/chloroform resulted in the formation of the disulfone $10(87 \%)$. By sulfone pyrolysis ${ }^{5)}$ of 10 at $580-600^{\circ} \mathrm{C}$ / $2 \cdot 10^{-6}$ Torr $6,7,11,12,19,20,24,25$-octahydro[3.3](2,7)pyrenophane (11), together with some partially dehydrogenated product, was obtained in $25 \%$ yield. Dehydrogenation $\left(\mathrm{Pd} / \mathrm{C}, 1\right.$-methylnaphthalene, $\left.24 \mathrm{~h}, 245^{\circ} \mathrm{C}\right)$ converted 11 into $1(72 \%)$.

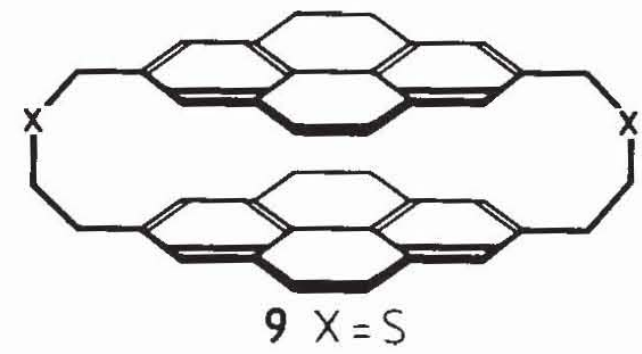

$10 \mathrm{X}=\mathrm{SO}_{2}$

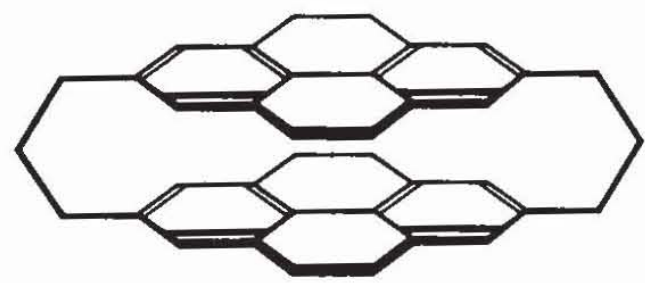

11

1 crystallized in yellow plates $\left(\mathrm{dec} .>355^{\circ} \mathrm{C}\right)$. Elemental analysis and spectroscopic properties are in accordance with structure $1\left[{ }^{1} \mathrm{H} \mathrm{NMR}\left(\mathrm{CDCl}_{3}, 360 \mathrm{MHz}\right): \delta=\right.$ $2.50-2.61(\mathrm{~m}, 4 \mathrm{H}), 3.15-3.31(\mathrm{~m}, 8 \mathrm{H}), 7.378(\mathrm{~s}, 8 \mathrm{H}), 7.405(\mathrm{~s}, 8 \mathrm{H})$. - MS: $m / z=$ $\left.484\left(100 \%, \mathrm{M}^{+}\right), 242\left(44, \mathrm{M}^{2+}\right), 230(41), 215(13)\right]$.

\section{Synthesis of [4.4](2,7)Pyrenophane (2)}

As in the case of the synthesis of $\mathbf{1}$, the preparation of the higher homologue 2 started from 2,7-bis(bromomethyl)-4,5,9,10-tetrahydropyrene (3) which by malonic ester synthesis yielded 2,7-bis[2,2-bis(methoxycarbonyl)ethyl]-4,5,9,10-tetrahydropyrene (12, 90\%). By demethoxycarbonylation ${ }^{6)}\left(\mathrm{NaCl} / \mathrm{H}_{2} \mathrm{O}\right.$, dimethyl sulfoxide, $3 \mathrm{~h}$, $160-170^{\circ} \mathrm{C} ; 59 \%$ ), 4,5,9,10-tetrahydro-2,7-bis[2-(methoxycarbonyl)ethyl]pyrene (13) was obtained which via 4,5,9,10-tetrahydro-2,7-bis(3-hydroxypropyl)pyrene (14; by lithium aluminum hydride reduction of $13 ; 97 \%$ ) was converted into the bis(bromopropyl) compound 15 (tetrabromomethane, triphenylphosphane; 73\%).

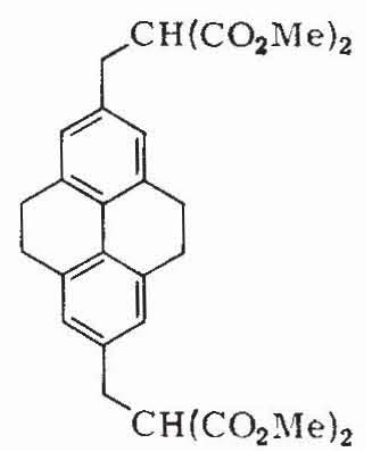

12

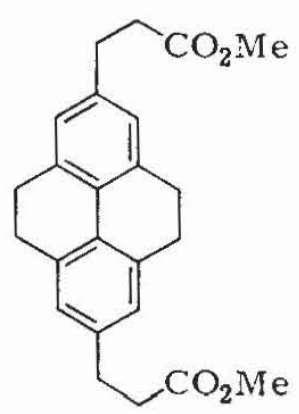

13

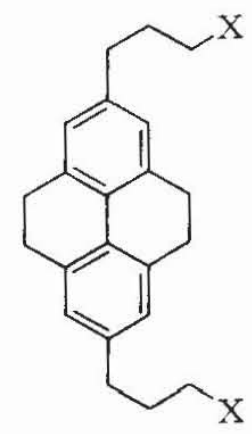

14: $\mathrm{X}=\mathrm{OH}$ 15: $\mathrm{X}=\mathrm{Br}$

Chem. Ber. 117(1984) 
Cyclisation of 15 with the bis(mercaptomethyl) compound $\mathbf{4}$ (potassium carbonate, methanol, high dilution) yielded $8,9,13,14,23,24,28,29$-octahydro-2,19-dithia[5.5](2,7)pyrenophane (16; 29\%) which was oxidized to the corresponding disulfone 17 (3-chloroperoxybenzoic acid, chloroform; $86 \%$ ). Gas-phase pyrolysis of 17 at $580-600^{\circ} \mathrm{C} / 10^{-6}$ Torr led to the octahydro[4.4](2,7)pyrenophane 18. Considering the very drastic conditions of this reaction and the fact that a 24-membered macrocyclic system is formed in a two-step reaction the pyrolysis yield of $69 \%$ is very remarkable. By dehydrogenation (DDQ, toluene) of 18 [4.4](2,7)pyrenophane (2) was obtained in $66 \%$ yield.

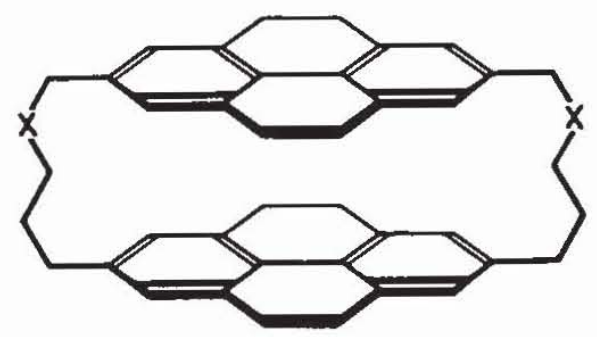

$16 x=5$

$17 \mathrm{X}=\mathrm{SO}_{2}$

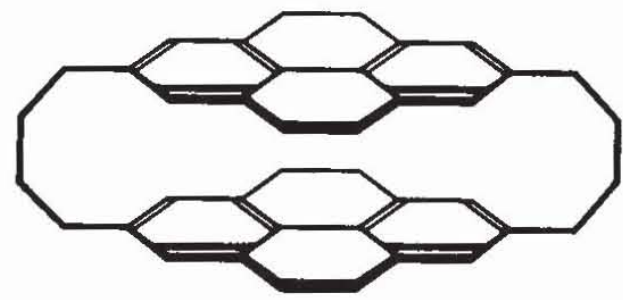

18

2 forms yellow crystals of mp $402-404^{\circ} \mathrm{C}$ (under argon). Elemental analysis and spectroscopic data agree with the structure suggested $\left[{ }^{1} \mathrm{H}\right.$ NMR $\left(\left[\mathrm{D}_{2}\right]-1,1,2,2\right.$-tetrachloroethane, $\left.100^{\circ} \mathrm{C}, 360 \mathrm{MHz}\right): \delta=2.16(\mathrm{br}$ 's', $8 \mathrm{H}), 2.78$ (br 's', $\left.8 \mathrm{H}\right), 7.276(\mathrm{~s}, 8 \mathrm{H})$, $7.293(\mathrm{~s}, 8 \mathrm{H})$. - MS: $\left.m / z=512\left(100 \%, \mathrm{M}^{+}\right), 256\left(12, \mathrm{M}^{2+}\right)\right]$.

\section{Molecular and Crystal Structures of 1 and $2^{7)}$}

$X$-Ray Structure Analysis: Crystal and data collection parameters of 1 and $\mathbf{2}$ are listed in Table 1. Intensity data were collected using a graphite-monochromated Mo- $K_{\alpha}$ radiation and applying $\Theta / 2 \Theta$-scan technique. The structures were solved by conventional direct methods (MULTAN) and were refined by full-matrix least-squares technique using anisotropic temperature factors for non-hydrogen atoms and isotropic temperature factors for hydrogen atoms. Atomic coordinates and thermal parameters for non-hydrogen atoms of 1 and 2 are given in Tables 2 and 3 (for numbering of atoms which for the sake of comparison between $\mathbf{1}$ and $\mathbf{2}$ differ from conventional phane rules see Figures $1 \mathrm{~A}$ and $2 \mathrm{~A}$ ).

Molecular Structure of 1: Figure 1 shows the molecular structure of 1 in a top-view perpendicular to the pyrene planes (A) and in a side-view (B). As expected the pyrene units in $\mathbf{1}$ are much less bent out of planarity than in the analogous [2.2]pyrenophane ${ }^{3 \mathrm{~d}}$. Whereas for the latter compound transanular distances vary from $279 \mathrm{pm}$ for the distance between the bridgehead carbons to $378 \mathrm{pm}$ for the interplanar distance in the center of the molecule, the corresponding distances in 1 are 318 and 348 pm. Thus, in spite of the longer bridges, in 1 there is considerable overlap of the two pyrene $\pi$-systems. In contrast to [2.2](2,7)pyrenophane where corresponding carbon atoms are nearly in ecliptic positions, for 1, however, a lateral displacement of $L=40 \mathrm{pm}$ in the long pyrene axis and $M=106 \mathrm{pm}$ perpendicular to that axis is found as shown in Figure $1 \mathrm{~A}$. As a consequence of this displacement the shortest transanular distance is not between corresponding carbon atoms (see Figure 1B).

Chem. Ber. 117 (1984) 
Table 1. Crystal and Data Collection Parameters for 1 and 2

\begin{tabular}{lll}
\hline Compound & $\mathbf{1}$ & $\mathbf{2}$ \\
\hline Formula & $\mathrm{C}_{38} \mathrm{H}_{28}$ & $\mathrm{C}_{40} \mathrm{H}_{32}$ \\
Molecular mass & 484.6 & 512.7 \\
$a[\mathrm{pm}]$ & $1005.2(2)$ & $1046.8(3)$ \\
$b[\mathrm{pm}]$ & $1013.7(2)$ & $1016.5(2)$ \\
$c[\mathrm{pm}]$ & $1192.6(2)$ & $1255.2(2)$ \\
$\beta\left[{ }^{\circ}\right]$ & $91.05(2)$ & $96.29(2)$ \\
Space group & $P 2_{1} / c$ & $P 21_{1} / c$ \\
$Z$ & 2 & 2 \\
$D_{x}\left[\mathrm{gcm}^{-3}\right]$ & 1.32 & 1.28 \\
Max. sin $\Theta / \lambda\left[\mathrm{nm}^{-1}\right]$ & 6.2 & 6.7 \\
No. of reflections measured & 2404 & 2329 \\
No. of reflections with & 1611 & 1462 \\
$I \geqslant 1.96 \sigma(I)$ & & \\
$R$ & 0.043 & 0.060 \\
\hline
\end{tabular}

Table 2. Atomic Coordinates and Thermal Parameters $U_{\text {equ. }}$ (in $\mathrm{pm}^{2}$ ) of Non-Hydrogen Atoms of 1 (Numbers in Parentheses are Estimated Standard Deviations in the Last Quoted Digits)

\begin{tabular}{|c|c|c|c|c|}
\hline Atom & $x$ & 4 & $z$ & Uequ \\
\hline$c(1)$ & $0.3603(2)$ & 0. $1886(2)$ & 0.4489 (1) & $465(5)$ \\
\hline$[(2)$ & $0.2377(2)$ & $0.2498(2)$ & $0.4627(1)$ & $455(5)$ \\
\hline$c(3)$ & $0.2299(2)$ & $0.3528(2)$ & $0.5391(1)$ & $430(5)$ \\
\hline$C(3 A)$ & $0.3418(2)$ & $0.4015(2)$ & $0.5965(1)$ & $371(4)$ \\
\hline$c(3 B)$ & $0.4672(2)$ & $0.3417(2)$ & $0.5781(1)$ & $358(4)$ \\
\hline$c(4)$ & $0.3355(2)$ & $0.5138(2)$ & $0.6692(1)$ & $410(4)$ \\
\hline$c(5)$ & $0.4464(2)$ & $0.5652(2)$ & $0.7172(1)$ & $416(4)$ \\
\hline$C(5 A)$ & $0.5752(2)$ & $0.5093(2)$ & $0.6985(1)$ & $368(4)$ \\
\hline$C(5 B)$ & $0.5840(2)$ & $0.3957(2)$ & $0.6296(1)$ & $355(4)$ \\
\hline$c(6)$ & $0.6912(2)$ & $0.5677(2)$ & $0.7396(1)$ & $437(5)$ \\
\hline$C(7)$ & $0.8163(2)$ & $0.5197(2)$ & $0.7131(1)$ & $453(5)$ \\
\hline$C(8)$ & $0.8243(2)$ & $0.4036(2)$ & $0.6511(1)$ & $463(5)$ \\
\hline$C(B A)$ & $0.7111(2)$ & $0.3400(2)$ & $0.6082(1)$ & $405(4)$ \\
\hline$C(9)$ & $0.7153(2)$ & $0.2238(2)$ & $0.5386(1)$ & $464(5)$ \\
\hline$c(10)$ & $0.6047(2)$ & $0.1738(2)$ & $0.4897(1)$ & $471(5)$ \\
\hline$C(18 A)$ & $0.4761(2)$ & $0.2316(2)$ & $0.5050(1)$ & $405(4)$ \\
\hline$c(11)$ & $0.9380(2)$ & $0.6011(2)$ & $0.7411(1)$ & $552(5)$ \\
\hline$c(12)$ & $0.9824(2)$ & $0.6898(2)$ & $0.6449(2)$ & $551(5)$ \\
\hline$C(13)$ & $0.8835(2)$ & $0.7959(2)$ & $0.6053(2)$ & $593(6)$ \\
\hline
\end{tabular}


Table 3. Atomic Coordinates and Thermal Parameters $U_{\text {equ. }}$ (in $\mathrm{pm}^{2}$ ) of Non-Hydrogen Atoms of 2 (Numbers in Parentheses are Estimated Standard Deviations in the Last Quoted Digits)

\begin{tabular}{|c|c|c|c|c|}
\hline Atom & $x$ & 4 & $z$ & Uequ \\
\hline$C(1)$ & $0.2206(3)$ & $0.3636(3)$ & $0.6385(2)$ & $573(9)$ \\
\hline$C(2)$ & $8.2290(3)$ & $0.4718(3)$ & $0.7062(2)$ & $579(9)$ \\
\hline$C(3)$ & $0.3464(3)$ & $0.5344(3)$ & $0.7282(2)$ & $566(9)$ \\
\hline$C(3 A)$ & $0.4557(2)$ & $0.4923(3)$ & $0.6836(2)$ & $495(8)$ \\
\hline$C(3 B)$ & $0.4469(2)$ & $0.3819(3)$ & $0.6139(2)$ & $458(8)$ \\
\hline$c(4)$ & $0.5781(3)$ & $0.5569(3)$ & $0.7056(2)$ & $581(9)$ \\
\hline$C(5)$ & $0.6824(3)$ & $0.5146(3)$ & $0.6620(2)$ & $571(9)$ \\
\hline$C(5 A)$ & $0.6769(2)$ & $0.4023(3)$ & $0.5916(2)$ & $505(8)$ \\
\hline$C(5 B)$ & $0.5575(2)$ & $0.3368(3)$ & $0.5681(2)$ & $456(8)$ \\
\hline$c(6)$ & $0.7833(3)$ & $0.3556(3)$ & $0.5460(2)$ & $585(9)$ \\
\hline$C(7)$ & $0.7776(3)$ & $0.2466(3)$ & $0.4784(2)$ & $573(9)$ \\
\hline$C(8)$ & $0.6602(3)$ & $0.1843(3)$ & $0.4550(2)$ & $599(9)$ \\
\hline$C(8 A)$ & $0.5492(3)$ & $0.2260(3)$ & $0.4984(2)$ & $505(8)$ \\
\hline$C(9)$ & $0.4269(3)$ & $0.1625(3)$ & $0.4771(2)$ & $575(9)$ \\
\hline$C(10 A)$ & $0.3271(3)$ & $0.3164(3)$ & $0.5914(2)$ & $498(8)$ \\
\hline$C(10)$ & $0.3225(3)$ & $0.2044(3)$ & $0.5213(2)$ & $570(9)$ \\
\hline$[(11)$ & $0.8988(3)$ & $0.1962(3)$ & $0.4353(3)$ & $750(10)$ \\
\hline$c(12)$ & $0.9742(3)$ & $0.3028(3)$ & $0.3784(3)$ & $780(10)$ \\
\hline$C(13)$ & $0.9170(3)$ & $0.3333(3)$ & $0.2652(3)$ & $830(10)$ \\
\hline$C(14)$ & $0.8862(3)$ & $0.4784(3)$ & $0.2423(2)$ & $740(10)$ \\
\hline
\end{tabular}

Table 4. C . C Bond Lengths of 1 and 2 (in pm; Numbers in Parentheses are Estimated Standard Deviations in the Last Quoted Digit)

\begin{tabular}{|c|c|c|c|c|c|c|c|}
\hline & & $\underline{1}$ & $\underline{2}$ & & & $\stackrel{1}{=}$ & $\underline{2}$ \\
\hline$c(1)$ & $-c(2)$ & $139.3(2)$ & $138.6(3)$ & $C(5 A)$ & $-c(6)$ & $138.9(2)$ & $139.0(3)$ \\
\hline$c(1)$ & $-C(I O A)$ & $140.1(2)$ & $140.3(3)$ & $C(5 B)$ & $-C(8 A)$ & $142.4(2)$ & $142.3(3)$ \\
\hline$c(2)$ & $-c(3)$ & $138.9(2)$ & $138.5(3)$ & $C(6)$ & $-C(7)$ & $138.9(2)$ & $139.2(3)$ \\
\hline$c(2)$ & $-C\left(13^{\circ}\right)$ & $152.2(2)$ & - & $c(7)$ & $-c(8)$ & $139.3(2)$ & $138.5(3)$ \\
\hline$c(2)$ & $-C\left(14^{\prime}\right)$ & - & $151.6(3)$ & $c(7)$ & $-c(11)$ & $150.9(2)$ & $152.2(3)$ \\
\hline$c(3)$ & $-C(3 A)$ & $139.6(2)$ & $139.4(3)$ & $C(8)$ & $-C(8 A)$ & $139.6(2)$ & $140.1(3)$ \\
\hline$C(3 A)$ & $-C(3 B)$ & $142.0(2)$ & $142.0(3)$ & $C(8 A)$ & $-c(9)$ & $144.2(2)$ & $143.2(3)$ \\
\hline$C(3 A)$ & $-c(4)$ & $143.4(2)$ & $143.9(3)$ & $c(9)$ & $-c(10)$ & $134.5(2)$ & $134.8(3)$ \\
\hline$C(3 B)$ & $-C(5 B)$ & $142.4(2)$ & $142.4(3)$ & $c(10)$ & $-c(1 O A)$ & $143.5(2)$ & $143.6(3)$ \\
\hline$C(3 B)$ & $-C(1 O A)$ & $142.0(2)$ & $142.1(3)$ & $C(11)$ & $-c(12)$ & $153.0(2)$ & $155.9(3)$ \\
\hline$C(4)$ & $-c(5)$ & $134.8(2)$ & $134.4(3)$ & $C(12)$ & $-c(13)$ & $153.4(2)$ & $151.2(3)$ \\
\hline$c(5)$ & $-c(5 A)$ & $143.5(2)$ & $144.1(3)$ & $c(13)$ & $-c(14)$ & - & $153.0(3)$ \\
\hline$C(5 A)$ & $-C(5 B)$ & $141.8(2)$ & $141.8(3)$ & & & & \\
\hline
\end{tabular}

Chem. Ber. $117(1984)$ 
Table 5. Bond Angles of 1 and 2 (in ${ }^{\circ}$; Numbers in Parentheses are Estimated Standard Deviations in the Last Quoted Digit)

\begin{tabular}{|c|c|c|c|c|c|c|c|c|c|}
\hline & & & $\stackrel{1}{\equiv}$ & $\mathbf{2}$ & & & & $\stackrel{1}{=}$ & $\stackrel{2}{2}$ \\
\hline$c(2)$ & $-c(1)$ & $-C(10 A)$ & $122.3(1)$ & $122.0(2)$ & $C(3 B)$ & $-C(5 B)$ & $-C(B A)$ & $120.4(1)$ & $120.4(2)$ \\
\hline$c(1)$ & $-c(2)$ & $-c(3)$ & $118.2(1)$ & $118.8(2)$ & $C(5 A)$ & $-C(5 B)$ & $-C(8 A)$ & $119.4(1)$ & $119.5(2)$ \\
\hline$c(1)$ & $-c(2)$ & $-c\left(13^{\circ}\right)$ & $120.2(1)$ & - & $C(5 A)$ & $-c(6)$ & $-c(7)$ & $121.8(1)$ & $122.6(2)$ \\
\hline$c(1)$ & $-c(2)$ & $-c\left(14^{\prime}\right)$ & - & $121.7(3)$ & $c(6)$ & $-c(7)$ & $-c(8)$ & $118.5(1)$ & $118.1(2)$ \\
\hline$c(3)$ & $-c(2)$ & $-c\left(13^{\prime}\right)$ & $121.6(1)$ & - & $c(6)$ & $-c(7)$ & $-c(11)$ & $119.4(1)$ & $120.1(3)$ \\
\hline$c(3)$ & $-c(2)$ & $-c\left(14^{\prime}\right)$ & - & $119.5(3)$ & $c(8)$ & $-c(7)$ & $-c(11)$ & $121.7(1)$ & $121.7(3)$ \\
\hline$c(2)$ & $-c(3)$ & $-C(3 A)$ & $122.2(1)$ & $121.9(2)$ & $c(7)$ & $-c(8)$ & $-C(8 A)$ & $122.0(1)$ & $122.2(2)$ \\
\hline$c(3)$ & $-c(3 A)$ & $-C(3 B)$ & $118.9(1)$ & $119.3(2)$ & $C(5 B)$ & $-C(8 A)$ & $-c(8)$ & $118.6(1)$ & $118.7(2)$ \\
\hline$c(3)$ & $-c(3 A)$ & $-c(4)$ & $122.2(1)$ & $122.4(2)$ & $C(5 B)$ & $-C(8 A)$ & $-c(9)$ & $117.5(1)$ & $117.7(2)$ \\
\hline$C(3 B)$ & $-C(3 A)$ & $-C(4)$ & $118.8(1)$ & $118.3(2)$ & $c(8)$ & $-C(8 A)$ & $-c(9)$ & $123.8(1)$ & $123.6(2)$ \\
\hline$C(3 A)$ & $-C(3 B)$ & $-C(5 B)$ & $119.8(1)$ & $120.2(2)$ & $C(8 A)$ & $-c(9)$ & $-c(10)$ & $121.6(1)$ & $121.9(2)$ \\
\hline$C(3 A)$ & $-C(38)$ & $-C(10 A)$ & $119.7(1)$ & $119.3(2)$ & $C(9)$ & $-c(10)$ & $-C(10 A)$ & $122.1(1)$ & $121.9(2)$ \\
\hline$C(5 B)$ & $-C(3 B)$ & $-C(10 A)$ & $120.4(1)$ & $120.5(2)$ & $C(1)$ & $-c(10 A)$ & $-C(3 B)$ & $118.5(1)$ & $118.7(2)$ \\
\hline$C(3 A)$ & $-C(4)$ & $-c(5)$ & $121.2(1)$ & $121.5(2)$ & $c(1)$ & $-c(1 O A)$ & $-c(10)$ & $123.7(1)$ & $123.7(2)$ \\
\hline$c(4)$ & $-c(5)$ & $-C(5 A)$ & $121.5(1)$ & $121.6(2)$ & $C(3 B)$ & $-C(1 O A)$ & $-c(10)$ & $117.8(1)$ & $117.6(2)$ \\
\hline$c(5)$ & $-c(5 A)$ & $-c(5 B)$ & $118.5(1)$ & $118.3(2)$ & $C(7)$ & $-c(11)$ & $-c(12)$ & $113.7(1)$ & $114.4(2)$ \\
\hline$c(5)$ & $-c(5 A)$ & $-c(6)$ & $122.1(1)$ & $122.9(2)$ & $c(11)$ & $-c(12)$ & $-c(13)$ & $116.5(1)$ & $113.9(3)$ \\
\hline$C(5 B)$ & $-C(5 A)$ & $-c(6)$ & $119.3(1)$ & $118.8(2)$ & $c\left(2^{\prime}\right)$ & $-c(13)$ & $-c(12)$ & $117.3(1)$ & - \\
\hline$C(3 B)$ & $-C(5 B)$ & $-c(5 A)$ & $120.2(1)$ & $120.1(2)$ & $c\left(2^{\circ}\right)$ & $-c(14)$ & $-c(13)$ & - & $113.7(2)$ \\
\hline
\end{tabular}
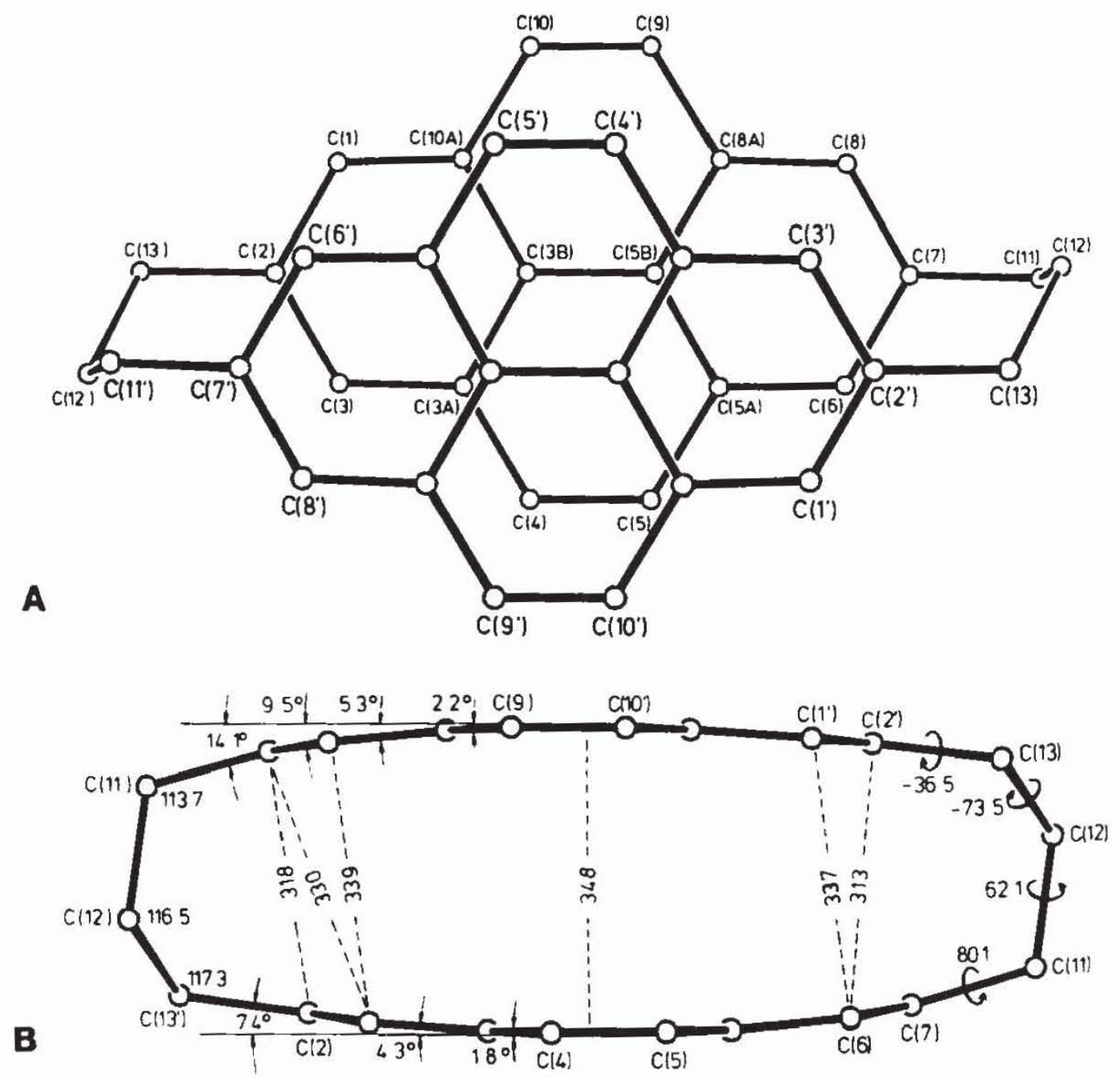

Figure 1. Molecular Structure of $\mathbf{1}$ in a Top-View (A) and in a Side-View (B) 

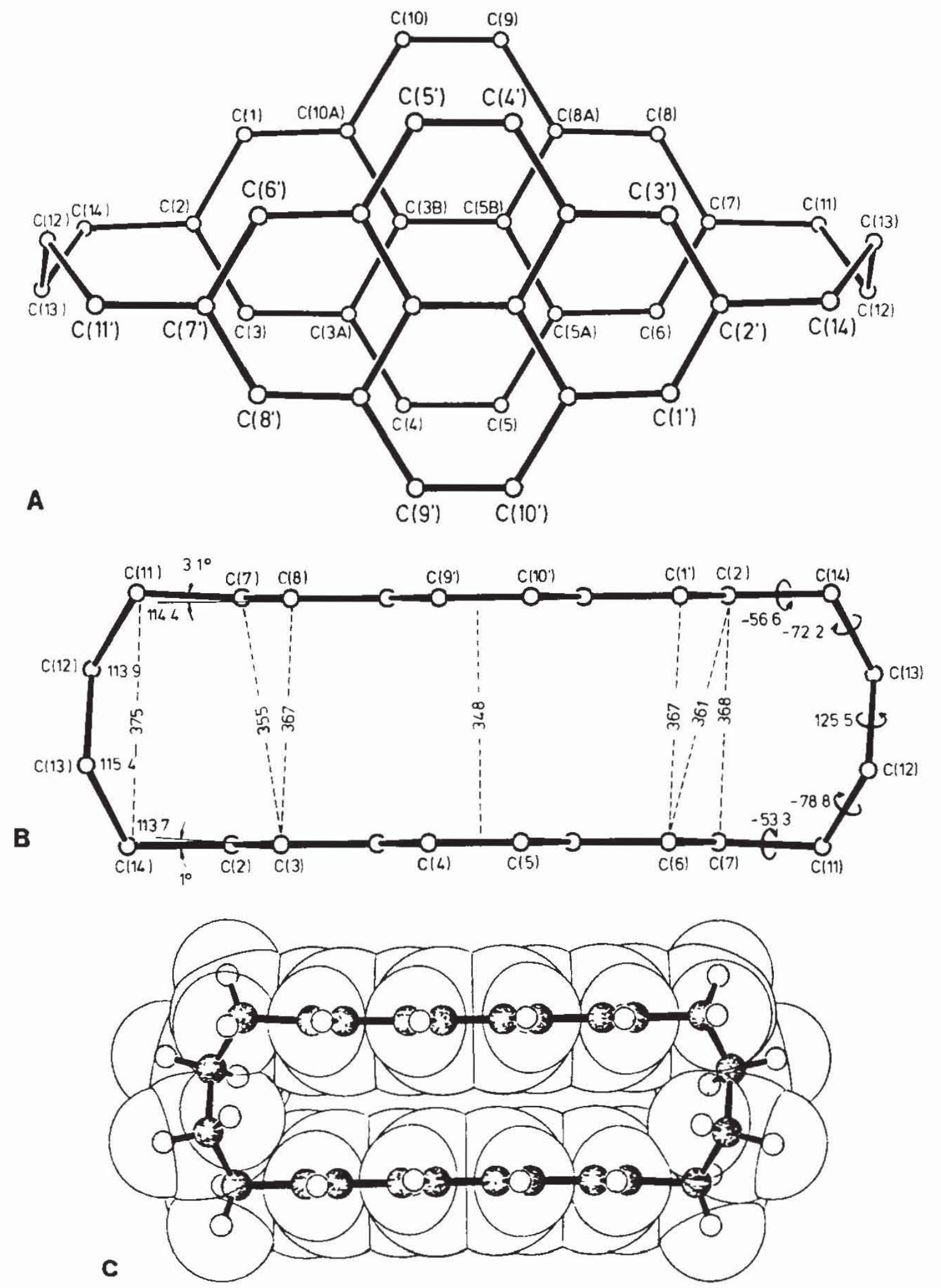

Figure 2. Molecular Structure of 2 in a Top-View (A), in a Side-View (B), and in a Side- $\backslash$ lew with van der Waals Radii (C)

The phane bridges $\left[C(11)-C(12)-C(13) / C\left(11^{\prime}\right)-C\left(12^{\prime}\right)-C\left(13^{\prime}\right)\right]$ in 1 show a 'chair'-like arrangement with staggered $\mathrm{C}-\mathrm{H}$ Bonds of neighbouring methylene groups (see torsional angles in Figure 1B). C . C C-bond lengths of 1 are listed together with those of $\mathbf{2}$ in Table 4 . In spite of the considerably different deformation cor- 
responding pyrene bond lengths in $[2.2](2,7)$ pyrenophane, $\mathbf{1}$ and $\mathbf{2}$ are very similar to each other and to those of 2,7-dimethylpyrene ${ }^{3 \mathrm{~d})}$. Bond angles of $\mathbf{1}$ and $\mathbf{2}$ are listed in Table 5.

Molecular Structure of 2: Figure 2 shows the molecular structure of $\mathbf{2}$ in a top-view along the projection upon the pyrene planes (A) and in a side-view (B). In contrast to $[2.2](2,7)$ pyrenophane ${ }^{3 d)}$ and to the [3.3]-analogue 1, the two pyrene units of the [4.4]pyrenophane 2 are of almost ideal planarity; the mean deviation of the carbon atoms from the best plane through all carbon atoms of a pyrene unit amounts to only $0.5 \mathrm{pm}$. With $348 \mathrm{pm}$ the transanular distance between the pyrene planes is well in the range of normal intermolecular distances of aromatic hydrocarbons (e.g., interplanar distance of 2,7-dimethylpyrene: $345 \mathrm{pm}^{3 \mathrm{~d}}$ ). Accordingly, 2 is a strain-free molecule with regard to transanular $\pi \cdots \pi$-interactions as is demonstrated in Figure $2 \mathrm{C}$ where the van der Waals radii are plotted into the framework of experimentally determined atomic positions of 2 .

As in 1 the pyrene units are not in an ecliptic arrangement to each other (Figure 2A). The lateral displacement is considerable perpendicular to the long pyrene axis $(M=$ $111 \mathrm{pm})$ whereas the parallel shift along this axis is rather small $(L=17 \mathrm{pm})$. Consequently, shortest transanular distances are not between corresponding carbon atoms (see Figure $2 \mathrm{~B}$ ). The $\mathrm{C}_{4}$-bridges of 2 form a zigzag conformation with staggered orientations of vicinal hydrogen atoms (for torsional angles see Figure $2 \mathrm{~B}$ ).

Bond lengths and angles of 2 are listed together with those of 1 in Tables 4 and 5 . In general, they are in the normal range as expected. The only exception is the short bond length of the central bond $\mathrm{C}(12)-\mathrm{C}(13)$ of the bridges. Similar results have been obtained from X-ray analyses of other [4.4]phanes ${ }^{8}$.

\section{Spectroscopic Properties of 1 and 2}

In the absorption spectrum of [2.2](2,7)pyrenophane, as compared to 2,7-dimethylpyrene, the absorption at longest wavelength appears strongly red-shifted as a broad, structureless band in the range of 380 to $430 \mathrm{~nm}^{3 \mathrm{c}}$. This red-shift and broadening, which is the result of transanular interactions ('phane effect'), is reduced in the absorption of the [3.3]pyrenophane $1\left[\lambda_{\max }=382 \mathrm{~nm}(\mathrm{sh}, \lg \varepsilon \approx 3.1), 368\right.$ (3.34), 328 (4.75), 314 (4.40), 271 (4.70), 259 (4.46), 237 (5.14); in dioxane]. For the [4.4]pyrenophane 2 the long-wavelength start of the absorption shows a further hypsochromic shift to about $410 \mathrm{~nm}$, and the vibration structure is still more pronounced [ $\lambda_{\max }=380 \mathrm{~nm}$

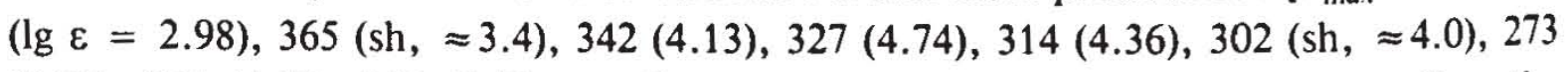
(4.72), 261 (4.55), 239 (5.22); in dioxane]. Thus, the absorption spectra reflect the decreasing transanular interactions in the series of [2.2]-, [3.3]-, and [4.4]pyrenophanes.

Fluorescence spectra of $\mathbf{1}$ and $\mathbf{2}$ in solution at room temperature as well as in glasses at very low temperature do not show the fluorescence of the pyrene chromophors but strongly red-shifted, broad, and structureless 'excimer-like' emissions, as is shown in Figure 3 for 2 (in 2-methyltetrahydrofuran glass, $1.3 \mathrm{~K}$ ). In Table 6 emission spectra of 1 and 2 are compared with those of [2.2](2,7)pyrenophane and 2,7-dimethylpyrene ${ }^{4)}$. The latter compound under the conditions mentioned shows the typical strongly 
vibration-structured fluorescence of a monomeric pyrene. With reference to this 2,7-dimethylpyrene fluorescence the excimer-like emissions of the pyrenophanes are redshifted for 4500 to $8250 \mathrm{~cm}^{-1}$. The red-shift decreases from [2.2](2,7)pyrenophane to the [3.3]-analogue 1 and further to the [4.4]phane 2. If these red-shifts are, however, corrected by considering the differences in the long-wavelength beginning of the absorptions nearly the same red-shift is found for all three pyrenophanes which is comparable to the red-shift of the excimer from pyrene itself $\left(\Delta v=5050 \mathrm{~cm}^{-1} ; 2\right.$-methyltetrahydrofuran, $298 \mathrm{~K}$ ).

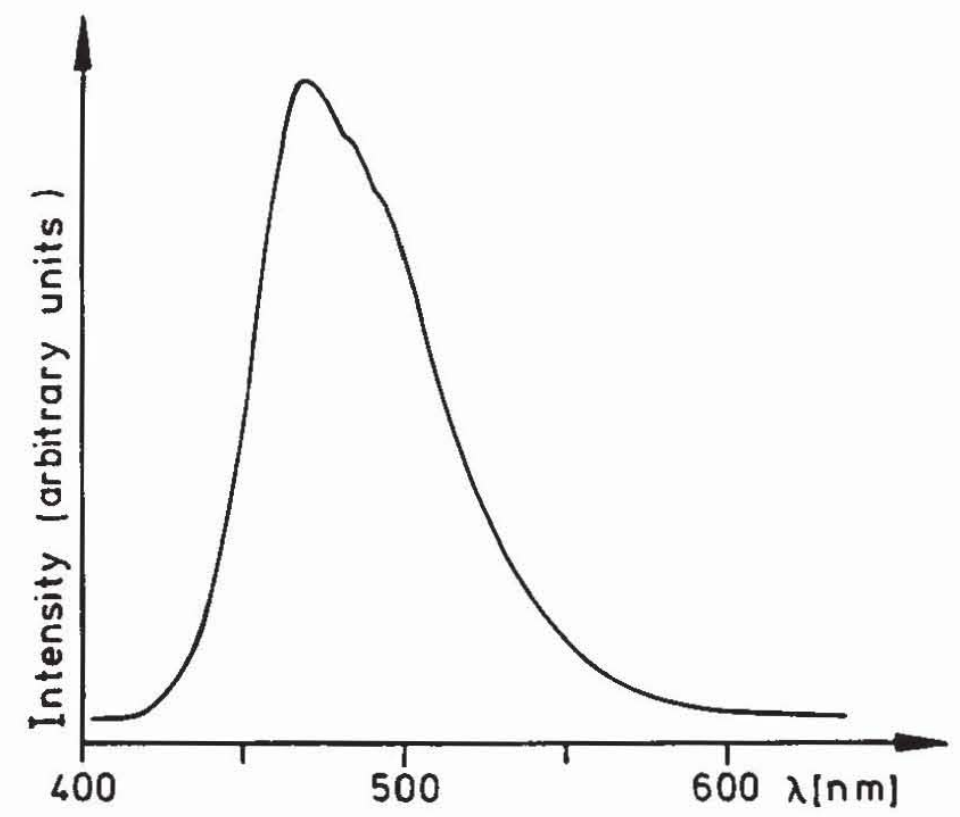

Figure 3. Fluorescence Emission of 2 in 2-Methyltetrahydrofuran at $1.3 \mathrm{~K}$ (Excitation at $361 \mathrm{~nm}$, $\mathrm{Kr}$ Laser)

Table 6. Emission Spectra at 1.3 K (MTHF: 2-Methyltetrahydrofuran)

\begin{tabular}{|c|c|c|c|c|}
\hline \multirow{2}{*}{ Compound } & \multirow{2}{*}{ Matrix } & \multicolumn{2}{|c|}{$\begin{array}{l}\text { Fluorescence } \\
{\left[\mathrm{cm}^{-1}\right]}\end{array}$} & \multirow{2}{*}{$\begin{array}{l}\text { Phospho- } \\
\text { rescence } \\
v_{\max }\left[\mathrm{cm}^{-1}\right.\end{array}$} \\
\hline & & $v_{\max }$ & $\Delta v$ & \\
\hline 2,7-Dimethylpyrene 4 ) & MTHF & 25850 & (reference) & 16935 \\
\hline$[2.2](2,7)$ Pyrenophane ${ }^{4)}$ & $\begin{array}{l}\text { MTHF } \\
\text { Crystals }\end{array}$ & $\begin{array}{l}18000 \\
17600\end{array}$ & $\begin{array}{l}7850 \\
8250\end{array}$ & $\begin{array}{l}16690 \\
16785\end{array}$ \\
\hline$[3.3](2,7)$ Pyrenophane (1) & $\begin{array}{l}\text { MTHF } \\
\text { Crystals }\end{array}$ & $\begin{array}{l}19400 \\
19600\end{array}$ & $\begin{array}{l}6450 \\
6250\end{array}$ & 16890 \\
\hline [4.4](2,7)Pyrenophane (2) & $\begin{array}{l}\text { MTHF } \\
\text { Crystals }\end{array}$ & $\begin{array}{l}21300 \\
20800\end{array}$ & $\begin{array}{l}4550 \\
5050\end{array}$ & $\begin{array}{l}16800 \\
16100\end{array}$ \\
\hline
\end{tabular}

Whereas for $\mathbf{2}$ from X-ray structure determination and absorption spectra it must be concluded that ground-state interactions between the two pyrene $\pi$-systems are rather small, the pyrene units in $\mathbf{2}$ obviously are in a sterical arrangement which allows an intramolecular 'excimer state' to be reached upon excitation. In contrast to excimers known so far excimer emission from pyrenophanes is an intramolecular property and, therefore, independent of concentration. With these molecules a new principle of a complete spectral separation of absorption and emission has been realised ${ }^{9}$. 
As compared to the monomeric 2,7-dimethylpyrene the phosphorescence of the pyrenophanes is not significantly shifted (Table 6). This indicates that in the excited triplet state transanular interactions between the pyrene $\pi$-systems must be small. Accordingly, triplet zero field splitting parameters $D$ and $E$, measured by the ODMR technique ${ }^{4)}$, are very similar for pyrenophanes and for pyrene monomers $[1:|D|=$ $0.0842 \mathrm{~cm}^{-1},|E|=0.0165 \mathrm{~cm}^{-1} ; 2,7$-dimethylpyrene: $|D|=0.0855 \mathrm{~cm}^{-1},|E|=$ $0.0169 \mathrm{~cm}^{-1}$; in 2-methyltetrahydrofuran, $\left.1.3 \mathrm{~K}\right]$. From these results it can be concluded that for the triplet states of pyrenophanes at a given time the triplet electrons are confined to a single pyrene unit; electron separation by transanular transfer to the neighbouring pyrene $\pi$-system should result in a reduction of $|D|$ as has been observed for donor-acceptor cyclophanes ${ }^{10)}$.

We thank Stiftung Volkswagenwerk, Hannover, and Fonds der Chemischen Industrie, Frankfurt/Main, for generous support of this work.

\section{Experimental Part}

4,5,9,10-Tetrahydro-2,7-pyrenedimethanethiol (4): $10.0 \mathrm{~g}$ (25.5 mmol) of 2,7-bis(bromomethyl)$4,5,9,10$-tetrahydropyrene (3), prepared according to lit. ${ }^{3 \mathrm{a}, \mathrm{b})}$, and $5.0 \mathrm{~g}(65 \mathrm{mmol})$ of thiourea in $50 \mathrm{ml}$ of ethanol were heated for $3 \mathrm{~h}$ under reflux. After cooling and addition of ether the isothiuronium salt was filtered off, added to $6 \mathrm{~g}$ of sodium hydroxide in $100 \mathrm{ml}$ of water and boiled under nitrogen for $3 \mathrm{~h}$. Acidification with diluted hydrochloric acid yielded a colourless precipitate which was recrystallized from tetrachloromethane: $5.14 \mathrm{~g}(68 \%)$, colourless platelets, m.p. $189-191^{\circ} \mathrm{C}$ (lit. ${ }^{3 a)} 190-192^{\circ} \mathrm{C}$ ).

4,5,9,10-Tetrahydro-2,7-pyrenediacetonitrile (5): To a suspension of $10.0 \mathrm{~g}$ (204 mmol) of sodium cyanide in $300 \mathrm{ml}$ of dimethyl sulfoxide at $20^{\circ} \mathrm{C} 18.8 \mathrm{~g}(47.7 \mathrm{mmol})$ of 3 was added under stirring. After $30 \mathrm{~min}$ the reaction mixture was added to $1.5 \mathrm{l}$ of ice water, the precipitate was filtered off, washed with water, dried, and chromatographed from dichloromethane on silica: $11.3 \mathrm{~g}(83 \%)$; after recrystallisation from isopropyl alcohol/toluene $(4: 1)$ and sublimation at $160-170^{\circ} \mathrm{C} / 10^{-3}$ Torr m.p. $234-235^{\circ} \mathrm{C}$ (dec.).

$\mathrm{C}_{20} \mathrm{H}_{16} \mathrm{~N}_{2}$ (284.3) Calcd. C 84.48 H 5.67 N 9.85 Found C 84.29 H 5.65 N 9.88

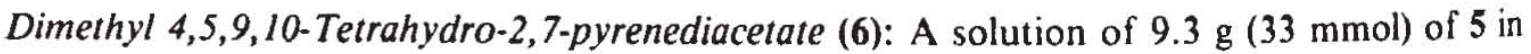
$150 \mathrm{ml}$ of methanol saturated with hydrogen chloride was heated under further passing through of hydrogen chloride for $3 \mathrm{~h}$ under reflux. The reaction mixture was given on 1.51 of ice water and the precipitate filtered off: $10.95 \mathrm{~g}(95 \%)$, m.p. $146-148^{\circ} \mathrm{C}$ (from methanol).

$$
\mathrm{C}_{22} \mathrm{H}_{22} \mathrm{O}_{4} \text { (350.4) Calcd. C } 75.41 \mathrm{H} 6.33 \text { Found C } 75.52 \mathrm{H} 6.36
$$

4,5,9,10-Tetrahydro-2,7-pyrenediethanol (7): To a boiling solution of $7.0 \mathrm{~g}(185 \mathrm{mmol})$ of lithium aluminum hydride in $100 \mathrm{ml}$ of tetrahydrofuran within $30 \mathrm{~min} 35.0 \mathrm{~g}$ (100 mmol) of 6 in $400 \mathrm{ml}$ of tetrahydrofuran was dropped under vigorous stirring. The mixture was heated under reflux for $4 \mathrm{~h}$. To the solution cooled with ice $20 \mathrm{ml}$ of water were added dropwise. The precipitate was filtered off and extracted with dichloromethane in a Soxhlet extractor. From filtrate and extract the solvents were distilled off, and the residue was crystallized from ethanol/toluene: $24.0 \mathrm{~g}(82 \%)$, m.p. $219-221^{\circ} \mathrm{C}$.

$$
\mathrm{C}_{20} \mathrm{H}_{22} \mathrm{O}_{2} \text { (294.4) Calcd. C } 81.60 \mathrm{H} 7.53 \text { Found C } 81.33 \mathrm{H} 7.62
$$

2,7-Bis(2-bromoethyl)-4,5,9,10-tetrahydropyrene (8): To a suspension of $14.7 \mathrm{~g}(50 \mathrm{mmol})$ of 7 in $41.5 \mathrm{~g}(125 \mathrm{mmol})$ of tetrabromomethane and $250 \mathrm{ml}$ of dichloromethane within $10 \mathrm{~min} 39.2 \mathrm{~g}$

Chem. Ber. $/ 17(1984)$ 
(150 mmol) of triphenylphosphane was added at $0^{\circ} \mathrm{C}$ under stirring. After $1 \mathrm{~h}$ at room temperature dichloromethane was distilled off, and $500 \mathrm{ml}$ of methanol was added. The precipitate was filtered off and recrystallized from ethanol/toluene: $18.4 \mathrm{~g}(88 \%)$, m.p. $220-222^{\circ} \mathrm{C}$ (dec.).

$\mathrm{C}_{20} \mathrm{H}_{20} \mathrm{Br}_{2}$ (420.2) Calcd. C $57.17 \mathrm{H} 4.80 \mathrm{Br} 38.03$ Found C $57.40 \mathrm{H} 4.78 \mathrm{Br} 37.98$

$7,8,12,13,21,22,26,27-$ Octahydro-2,17-dithia[4.4](2,7)pyrenophane (9): A solution of $2.54 \mathrm{~g}$ ( $8.5 \mathrm{mmol})$ of 4 and $3.58 \mathrm{~g}(8.5 \mathrm{mmol})$ of 8 in $500 \mathrm{ml}$ of toluene was dropped within $12 \mathrm{~h}$ under nitrogen to a boiling mixture of $5 \mathrm{~g}$ of potassium carbonate, $1 \mathrm{l}$ of ethanol $(95 \%)$, and $1 \mathrm{I}$ of tertbutyl alcohol. The solvents were distilled off; the residue was chromatographed from dichloromethane on a short silica column and crystallized from benzonitrile: $2.5 \mathrm{~g}(53 \%)$, m.p. $300-302{ }^{\circ} \mathrm{C}$ (dec., under nitrogen). $-{ }^{1} \mathrm{H}-\mathrm{NMR}\left(\mathrm{CDCl}_{3}, 80 \mathrm{MHz}\right): \delta=2.56(\mathrm{~s}, 16 \mathrm{H}), 2.4-3.1$ $\left(\mathrm{AA}^{\prime} \mathrm{BB}^{\prime}, 8 \mathrm{H}\right), 3.44(\mathrm{~s}, 4 \mathrm{H}), 6.60(\mathrm{~s}, 4 \mathrm{H}), 6.67(\mathrm{~s}, 4 \mathrm{H})$. $-\mathrm{MS}: \mathrm{m} / z=556\left(37 \%, \mathrm{M}^{+}\right), 277(19)$, 245 (10), 233 (100), $232(50) ; \mathrm{M}^{+}$calcd. 556.2242, exp. 556.2258.

\section{$\mathrm{C}_{38} \mathrm{H}_{36} \mathrm{~S}_{2}$ (556.8) Calcd. C 81.97 H $6.52 \mathrm{~S} 11.51$ Found C 81.78 H $6.76 \mathrm{~S} 11.78$}

7,8,12,13,21,22,26,27-Octahydro-2,17-dithia/4.4](2, 7)pyrenophane-2,2,17,17-tetraoxide (10): To a suspension of $4.23 \mathrm{~g} \mathrm{(7.6} \mathrm{mmol)} \mathrm{of} 9$ in $350 \mathrm{ml}$ of chloroform $8.1 \mathrm{~g} \mathrm{(42} \mathrm{mmol)} \mathrm{of} \mathrm{3-chloroper-}$ oxybenzoic acid $(90 \%)$ was added. After addition of $200 \mathrm{ml}$ of chloroform, extraction with $10 \%$ sodium hydroxide solution, washing with water, and drying the solvent was distilled off. The residue was dissolved in boiling benzonitrile and the disulfone precipitated by addition of ethanol: $4.1 \mathrm{~g}(87 \%)$, m.p. $344-348^{\circ} \mathrm{C}$ (dec., under nitrogen).

$$
\mathrm{C}_{38} \mathrm{H}_{36} \mathrm{O}_{4} \mathrm{~S}_{2}(620.8) \text { Calcd. C } 73.52 \mathrm{H} 5.84 \mathrm{~S} 10.33 \text { Found C } 73.46 \text { H } 5.85 \mathrm{~S} 10.38
$$

$6,7,11,12,19,20,24,25$-Octahydro[3.3](2,7)pyrenophane (11): $514 \mathrm{mg}(0.828 \mathrm{mmol})$ of 10 was pyrolyzed in a pyrolysis apparatus ${ }^{5)}$ in samples of about $100 \mathrm{mg}$ each at $580-600^{\circ} \mathrm{C} / 2 \cdot 10^{-6}$ Torr (sublimation zone $300^{\circ} \mathrm{C}$; duration $5-8 \mathrm{~h}$ ). The product was chromatographed from tetrachloromethane on silica at $40-50^{\circ} \mathrm{C}$ and recrystallized from toluene: $104 \mathrm{mg}(25 \%)$. According to mass spectrum and ${ }^{1} \mathrm{H}$ NMR the product contains some partially dehydrogenated material; it is used for the following reaction without further purification.

[3.3] $(2,7)$ Pyrenophane (1): $51 \mathrm{mg}(0.104 \mathrm{mmol})$ of 11 and $5 \mathrm{ml}$ of 1 -methylnaphthalene were heated in the presence of $20 \mathrm{mg}$ of palladium (10\%)/activated charcoal $24 \mathrm{~h}$ under reflux. After addition of toluene to the reaction mixture the catalyst was filtered off at $100^{\circ} \mathrm{C}$. The solvents were distilled off in vacuo, and the residue was crystallized from toluene: $36 \mathrm{mg} \mathrm{(72 \% )}$ of 1 , yellow plates, dec. $>355^{\circ} \mathrm{C}$ (under nitrogen). $-{ }^{1} \mathrm{H}$ NMR, MS: see above.

$$
\mathrm{C}_{38} \mathrm{H}_{28} \text { (484.6) Calcd. C } 94.18 \text { H } 5.82 \text { Found C } 94.19 \text { H } 6.01
$$

Tetramethyl 2,2'-[4,5,9,10-Tetrahydro-2,7-pyrenediylbis(methylene)]bispropanedioate (12): To a solution of $5.1 \mathrm{~g}(220 \mathrm{mmol})$ of sodium in $200 \mathrm{ml}$ of methanol $30 \mathrm{~g}(225 \mathrm{mmol})$ of dimethyl malonate was added at $20^{\circ} \mathrm{C}$ under stirring. After $\left.30 \mathrm{~min} 39.2 \mathrm{~g} \mathrm{(100} \mathrm{mmol}\right)$ of 3 was added, and the suspension formed was heated under reflux for $5 \mathrm{~h}$ with stirring. After cooling the precipitate was filtered off, washed with methanol, and dried: $45 \mathrm{~g}(90 \%)$; crystallized from methyl acetate: colourless crystals, m.p. $151-152^{\circ} \mathrm{C}$.

$$
\mathrm{C}_{28} \mathrm{H}_{30} \mathrm{O}_{8} \text { (494.5) Calcd. C } 68.00 \mathrm{H} 6.12 \text { Found C } 67.91 \text { H } 6.09
$$

Dimethyl 4,5,9,10-Tetrahydro-2, 7-pyrenedipropionate (13): $45 \mathrm{~g}$ (90 mmol) of 12 and $12 \mathrm{~g}$ (205 mmol) of sodium chloride were heated under stirring in $50 \mathrm{ml}$ of dimethyl sulfoxide and $5 \mathrm{ml}$ of water for $3 \mathrm{~h}$ to $160-170^{\circ} \mathrm{C}$. After cooling to room temperature $500 \mathrm{ml}$ of dichloromethane and $500 \mathrm{ml}$ of water were added. The separated aqueous phase was acidified with diluted hydrochloric acid and three times extracted with dichloromethane. The united dichloromethane solutions were washed with water, dried with sodium sulfate, and evaporated in vacuo. The residue was 
chromatographed from toluene/ethyl acetate (4:1) on silica and crystallized from acetone: $20 \mathrm{~g}$ $(59 \%)$, colourless platelets, m.p. $186-187^{\circ} \mathrm{C}$ (from methyl acetate).

$$
\mathrm{C}_{24} \mathrm{H}_{26} \mathrm{O}_{4} \text { (378.5) Calcd. C } 76.16 \mathrm{H} 6.93 \text { Found C } 76.18 \text { H } 6.83
$$

4,5,9,10-Tetrahydro-2,7-pyrenedipropanol (14): To a solution of $2.6 \mathrm{~g}$ (70 mmol) of lithium aluminum hydride in $50 \mathrm{ml}$ of boiling tetrahydrofuran a solution of $18.9 \mathrm{~g}(50 \mathrm{mmol})$ of 13 in $250 \mathrm{ml}$ of tetrahydrofuran was dropped under stirring within $1 \mathrm{~h}$. After $4 \mathrm{~h}$ heating under reflux to the reaction mixture, cooled in ice water, $6 \mathrm{ml}$ of water was added dropwise. The precipitate was filtered off and extracted in a Soxhlet extractor with dichloromethane. From the united filtrate and extract the solvents were distilled off: $15.7 \mathrm{~g} \mathrm{(97 \% )}$ of 14 which was used for the following reaction without further purification. Crystallized from acetonitrile $\mathbf{1 4}$ forms colourless platelets, m.p. $223-225^{\circ} \mathrm{C}$.

$$
\mathrm{C}_{22} \mathrm{H}_{26} \mathrm{O}_{2}(322.4) \text { Calcd. C } 81.95 \text { H } 8.13 \text { Found } \mathrm{C} 81.95 \text { H } 8.21
$$

2,7-Bis(3-bromopropyl)-4,5,9,10-tetrahydropyrene (15): To a suspension of $16.1 \mathrm{~g}$ (50 mmol) of 14 in $41.5 \mathrm{~g}$ (125 mmol) of tetrabromomethane and $250 \mathrm{ml}$ of dichloromethane $39.2 \mathrm{~g}$ (150 mmol) of triphenylphosphane was added slowly under ice-cooling. After $30 \mathrm{~min}$ the solvent was distilled off; $500 \mathrm{ml}$ of methanol was added to the residue, and the precipitate was filtered off and washed with methanol. Chromatography from dichloromethane on silica yielded $18 \mathrm{~g}(73 \%)$, colourless crystals, m.p. $167-169^{\circ} \mathrm{C}$ (from $n$-hexane).

\section{$\mathrm{C}_{22} \mathrm{H}_{24} \mathrm{Br}_{2}$ (448.2) Calcd. C 58.95 H $5.40 \mathrm{Br} 35.65$ Found C 59.19 H $5.24 \mathrm{Br} 35.69$}

$8,9,13,14,23,24,28,29$-Octahydro-2,19-dithia[5.5](2,7)pyrenophane (16): The solution of $11.2 \mathrm{~g}$ ( $25 \mathrm{mmol})$ of 15 and $8.2 \mathrm{~g} \mathrm{(25} \mathrm{mmol)} \mathrm{of} 4$ in $1250 \mathrm{ml}$ of toluene was dropped at constant rate (magnetic valve) within $30 \mathrm{~h}$ to a stirred, boiling solution of $14 \mathrm{~g}(120 \mathrm{mmol})$ of potassium carbonate in 51 of methanol. The solvent was distilled off in vacuo and the residue was chromatographed on silica from toluene at $80-90^{\circ} \mathrm{C}: 4.3 \mathrm{~g}(29 \%)$. After crystallization from toluene: colourless crystals, m.p. $298-304^{\circ} \mathrm{C}$ (under argon). $-{ }^{1} \mathrm{H} \mathrm{NMR}\left(\mathrm{CDCl}_{3}, 80 \mathrm{MHz}\right): \delta=$ $1.65-2.1(\mathrm{~m}, 4 \mathrm{H}), 2.1-2.4(\mathrm{~m}, 4 \mathrm{H}), 2.4-2.75(\mathrm{~m}, 4 \mathrm{H}), 2.55(\mathrm{~s}, 16 \mathrm{H}), 3.59(\mathrm{~s}, 4 \mathrm{H}), 6.63(\mathrm{~s}$, $4 \mathrm{H}), 6.74(\mathrm{~s}, 4 \mathrm{H})$. - MS: $m / z=584\left(34 \%, \mathrm{M}^{+}\right), 351(12), 233(100)$.

$$
\mathrm{C}_{40} \mathrm{H}_{40} \mathrm{~S}_{2} \text { (584.9) Calcd. C } 82.14 \text { H } 6.89 \mathrm{~S} 10.96 \text { Found C } 82.25 \text { H } 6.81 \mathrm{~S} 10.73
$$

8,9,13,14,23,24,28,29-Octahydro-2,19-dithia[5.5](2,7)pyrenophane-2,2,19,19-tetraoxide (17): To a solution of $1.17 \mathrm{~g}(2.0 \mathrm{mmol})$ of 16 in $50 \mathrm{ml}$ of chloroform $2.3 \mathrm{~g} \mathrm{(12} \mathrm{mmol)} \mathrm{of} \mathrm{3-chloroper-}$ oxybenzoic acid was added, and the solution was stirred for $2 \mathrm{~h}$ at room temperature. After extraction with $10 \%$ sodium hydroxide solution, washing with water, and drying over sodium sulfate the solvent was distilled off. To the residue $50 \mathrm{ml}$ of ether was added; the precipitate was filtered off and dried: $1.11 \mathrm{~g}(86 \%)$ of the disulfone 17 which was pyrolyzed without further purification. For analysis the material was crystallized from chloroform/ethyl acetate: colourless crystals, m.p. $382-384^{\circ} \mathrm{C}$ (dec., under argon).

$$
\mathrm{C}_{40} \mathrm{H}_{40} \mathrm{O}_{4} \mathrm{~S}_{2} \text { (648.9) Calcd. C } 74.04 \text { H } 6.21 \mathrm{~S} 9.88 \text { Found C } 73.91 \text { H } 6.30 \mathrm{~S} 9.63
$$

$7,8,12,13,21,22,26,27-$ Octahydro[4.4](2,7)pyrenophane (18): $1.08 \mathrm{~g}(1.66 \mathrm{mmol})$ of 17 , in samples of $200-250 \mathrm{mg}$ each, was pyrolyzed in a pyrolysis apparatus ${ }^{5)}$ at $580-600^{\circ} \mathrm{C} / 10^{-6} \mathrm{Torr}$ (sublimation zone $280-300^{\circ} \mathrm{C}$; duration $5-8 \mathrm{~h}$ ). The pyrolysates were chromatographed from tetrachloromethane on silica at $40^{\circ} \mathrm{C}: 588 \mathrm{mg}(69 \%)$, after crystallization from toluene $/ n$-hexane (1:1) colourless crystals, m.p. $364-368^{\circ} \mathrm{C}$ (under argon). - ${ }^{1} \mathrm{H} \mathrm{NMR}\left(\mathrm{CDCl}_{3}, 360 \mathrm{MHz}\right): \delta=$ 1.66 ('s', $8 \mathrm{H}), 2.35$ ('s', 8H), $2.47-2.67$ (AA'BB', 16H), 6.53 (s, 8H). - MS: $m / z=520(100 \%$, $\mathrm{M}^{+}$), $518(7), 259$ (7), 245 (6), 232 (28), 219 (8), 217 (10), 215 (8), 203 (7), 202 (10).

$$
\mathrm{C}_{40} \mathrm{H}_{40}(520.7) \text { Calcd. C } 92.26 \text { H } 7.74 \text { Found C } 92.48 \text { H } 7.95
$$

Chem. Ber. 117(1984) 
[4.4](2,7)Pyrenophane (2): To $52 \mathrm{mg}(0.10 \mathrm{mmol})$ of $18 \mathrm{in} 10 \mathrm{ml}$ of boiling toluene a solution of $100 \mathrm{mg}(0.44 \mathrm{mmol})$ of 2,3-dichloro-5,6-dicyano-1,4-benzoquinone (DDQ) in $10 \mathrm{ml}$ of toluene was added under stirring. After further heating until the solution was decolourized (approx. $2 \mathrm{~h}$ ) the solvent was distilled off in vacuo, the residue was suspended in boiling ethanol, filtered off, and chromatographed at $80-90^{\circ} \mathrm{C}$ from toluene on silica: $34 \mathrm{mg}(66 \%)$, yellow crystals (from toluene), m.p. $402-404^{\circ} \mathrm{C}$ (under argon). $-{ }^{1} \mathrm{H}$ NMR, MS: see above.

$$
\mathrm{C}_{40} \mathrm{H}_{32} \text { (512.7) Calcd. C } 93.71 \text { H } 6.29 \text { Found C } 93.72 \text { H } 6.56
$$

1) Th. Förster and K. Kasper, Z. Phys. Chem. (Frankfurt am Main) 1, 275 (1954); s. also Th. Fòrster, Angew. Chem. 81, 364 (1969); Angew. Chem., Int. Ed. Engl. 8, 333 (1969).

2) Cf. H. A. Staab and M. Haenel, Chem. Ber. 106, 2190 (1973); M. Haenel and H. A. Staab, ibid. 106, 2203 (1973); D. Schweltzer, J. P. Colpa, J. Behnke, K. H. Hausser, M. Haenel, and H. A. Staab, Chem. Phys. 11, 373 (1975); N. E. Blank and M. W. Haenel, Chem. Ber. 114, 1520,1531 (1981); there further references to literature are given.

3) 3a) T. Umemoto, S. Satani, Y. Sakata, and S. Misumi, Tetrahedron Lett. 1975, 3159. - 3b) $R$. H. Mitchell, R. J. Carruthers, and J. C. M. Zwinkels, Tetrahedron Lett. 1976, 2585. - 3c) $R$. G. H. Kirrstetter, Dissertation, Univ. Heidelberg 1976; H. A. Staab and R. G. H. Kirrstetter, Liebigs Ann. Chem. 1979, 886. - 3d) H. Irngartinger, R. G. H. Kirrstetter, C. Krieger, H. Rodewald, and H. A. Staab, Tetrahedron Lett. 1977, 1425.

4) D. Schweitzer, K. H. Hausser, R. G. H. Kirrstetter, and H. A. Staab, Z. Naturforsch., Teil A 31, 1189 (1976).

5) M. Haenel and H. A. Staab, Tetrahedron Lett. 1970, 3585; H. A. Staab and M. Haenel, Chem. Ber. 106, 2190 (1973).

6) Cf. A. P. Krapcho, Synthesis 1982, 805, 893.

7) Further information concerning the $X$-ray structure analyses of 1 and 2 may be requested from Fachinformationszentrum Energie Physik Mathematik, D-7514 Eggenstein-Leopoldshafen, with indication of the registry number CSD 50428, the authors' names, and the reference to this publication.

${ }^{8)}$ H. A. Staab, A. Dohling, and C. Krieger, Liebigs Ann. Chem. 1981, 1052; H. A. Staab, B. Starker, and C. Krieger, Chem. Ber. 116, 3831 (1983).

9) This principle might be of interest with regard to the development of fluorescent dyes for solar collectors. In this context, we would like to thank Dr. H. Langhals, Freiburg, for preliminary measurements of the absorption and emission of $[2.2](2,7)$ pyrenophane in polymethyl methacrylate.

${ }^{10)}$ D. Schweitzer, K. H. Hausser, V. Taglieber, and H. A. Staab, Chem. Phys. 14, 183 (1976); D. Schweitzer, K. H. Hausser, P. Wahl, and H. A. Staab, Bull. Magn. Reson. 2, 144 (1981).

[99/83] 